\title{
Um currículo entre formas e forças
}

\author{
A curriculum between formats and forces
}

\author{
Un currículo entre formas y fuerzas
}

\author{
MARLUCY AlVES PARAÍSO*
}

\begin{abstract}
RESUMO - Este artigo focaliza processos de diferenciação ocorridos nos currículos escolares e cenas de um livro A contadora de filmes - para mostrar, por um lado, como as formas de um currículo são capazes de produzir rotinas, aprisionar as forças, dividir e desanimar. Por outro lado, este trabalho também pretende mostrar que a diferença, entendida como motor da vida, pode sempre ser reativada, já que na vida é sempre possível um encontro ou uma conexão capaz de reativar forcas. Este artigo defende, então, que em um currículo e na vida é sempre possível movimentos para deformar as formas, reativar as forças, instaurar possibilidades e ativar alegrias.
\end{abstract}

Palavras-chave - Currículo. Diferença. Formas e forças.

ABSTRACT - This article focuses on process of differentiation occurred in school curriculums and in scenes of a book - The counter of films - to demonstrate, from one perspective, how the formats of a curriculum are capable of producing routines, imprisoning forces, dividing and discouraging. On the other hand, this work is also going to show that difference, understood as the motor of life, can always be reactivated, since, in life, a meeting or a connection capable of reactivating forces is always a possibility. This article defends, therefore, that in a curriculum and in life movements to deform formats, reactivate forces, establish possibilities and activate joy are always possible.

Keywords - Curriculum. Difference. Formats and forces.

RESUMEN - Este articulo enfoca los procesos de diferenciación que acontecen en los currículos escolares y fragmentos del libro - La contadora de películas - para mostrar, por un lado, como las formas de un currículo son capaces de producir rutinas, aprisionar fuerzas, dividir y desanimar. Por otro lado, este trabajo también pretende mostrar que la diferencia, entendida como motor de la vida, puede siempre ser reactivada, ya que en la vida siempre es posible un encuentro o una conexión capaz de reactivar las fuerzas. Por lo tanto, este articulo defiende, que en un currículo, como en la vida, siempre es posible movimientos para deformar las formas, reactivar las fuerzas, instaurar posibilidades y activar alegrías.

Palabras clave - Currículo. Diferencia. Formas y fuerzas.

\section{I - INTRODUÇÃO}

Um currículo pode estar feito da mesma matéria dos sonhos, nos quais tudo é possibilidade? Um currículo pode estar feito da mesma matéria da literatura, da filosofia vitalícia, da pintura, da poesia, de toda arte que sonha, delira, cria, encanta e faz sonhar? Um currículo pode estar feito da mesma matéria dos filmes que estão constantemente inventando outros possíveis? Em síntese: um currículo pode estar feito da mesma matéria de uma vida - que é como um mar aberto ou "uma onda do mar" onde "tudo move, tudo muda o tempo todo"l?

Shakespeare disse que "somos feitos do mesmo material dos sonhos" (LETELIER, 2012, p. 3). A Fada Docine - personagem criada por Hernán Letelier no livro A contadora de filmes -, em seu devir-artista de inspiração shakespeariana, diz que "somos feitos do mesmo material dos filmes" (LETELIER, 2012, p. 3). Pois eu, afetada por esse mundo de invenções que me faz pensar sobre as muitas matérias com os quais somos constituídos e

\footnotetext{
* Doutora em Educação pela Universidade Federal do Rio de Janeiro (Rio de Janeiro, RJ, Brasil) e professora na Universidade Federal de Minas Gerais (Belo Horizonte, MG, Brasil).E-mail: <marlucyparaiso@gmail.com>.
} 
constituímos os materiais ao nosso redor, defendo que um currículo, apesar de ser constituído de muitas formas, pode perfeitamente ser feito da mesma matéria dos sonhos, dos filmes e da vida. É claro que, para isso, um currículo precisa de outros pensamentos, raciocínios; ele necessita de uma outra lógica.

A busca de uma lógica para um currículo que esteja atenta às sensações; uma lógica para pensá-lo como um vetor de matéria-força para o aprender é o que mobiliza este artigo. Procuro aqui pensar um currículo como espaço de possibilidades e como território onde as forças podem "deformar" as formas de um currículo, instaurando o movimento que é fundamental para o aprender ${ }^{2}$. Um currículo constitui-se em matéria-forma que opera com a imitação, a ilustração e a representação porque objetiva uma "formatação", uma "identificação", uma "homogeneização", um determinado "desempenho" (PARAÍSO, 2010a, p. 132-133). O problema é que tudo isso paralisa o movimento, o ziguezaguear, o fluxo da vida. Se a forma paralisa o movimento, a força é deformadora das formas, mobilizadora da diferença e agenciadora de devires.

A força é instância condutora de movimentos que possibilitam deixar de ser. A força é fluxo que nos faz cair na linha de fuga de um devir. Ela é instância mobilizadora de encontros potentes que permitem encontrar a diferença de cada um. Inspirada na lógica das sensações que prioriza as forças - tão vital nos pensamentos de Antonin Artaud, de Gilles Deleuze e também na ética de Spinoza - move este trabalho a busca de uma saída para livrar um currículo da subordinação às formas; subordinação tão antiga quanto a própria existência de um currículo.

Seja qual for o caminho que percorro nessa busca por liberar as forças de um currículo, ele me leva a esse tema que, na contemporaneidade, não é mais possível escamotear: o tema da diferença. É isso que os Estudos Culturais têm insistentemente mostrado. É isso que fica evidente no pensamento da diferença. É isso que sentimos ao ver um filme, ao observar um currículo, ao vivenciar uma aula, ao andar nas ruas... Vivemos no tempo da diferença. Vivemos desse tema e com os inúmeros desafios que ele nos coloca. "Vivemos nessa e dessa problemática" (ORLANDI, 2005, p. 10). Afinal, é a problemática da diferença que tentamos abordar por partes, com recortes, com diferentes perspectivas quando tratamos de acesso desigual à educação, dos conflitos culturais no currículo, das lutas dos diferentes movimentos sociais por representação e do currículo como um campo de luta por produção de significados.

É a diferença que "tentamos exprimir aos pedaços", do modo como conseguimos, "seja quando nos interessamos por uma diferenciação, [...] seja quando deliramos a respeito de como enfrentar nossas próprias dores, seja quando criticamos a presunção de uma potência militar, seja quando tememos a violência do próximo ou a nossa própria e indefinida capacidade de odiar" (ORLANDI, 2005, p. 11). É a diferença também que está em foco quando, no campo do currículo, traçamos os novos mapas políticos e culturais contemporâneos, as multiculturalidades do nosso tempo, os processos pós-coloniais, as questões da diferença sexual, de gênero, etnia, raça, geração, sexualidades. É a diferença que tentamos exprimir quando, usando as diferentes contribuições dos Estudos Culturais, abordamos as múltiplas lutas de diferentes grupos pelo e no currículo, pela e na produção de saberes e quando tratamos da alteridade dos/as diferentes que desejam ser educados de modo a possibilitar viver suas próprias experiências.

Assim, seja a diferença entendida como prática produzida e produtora de discursos, de sentidos e de sujeitos; ou como marcas culturais que unem e separam pessoas, territórios, culturas; ou como significados que produzimos e adotamos e que nos faz ser e viver de determinados modos; ou como processo que divide, demarca, separa, ou, ainda e por fim, como fluxo e motor da vida que move, jorra forças e possibilita entrar em devires, é a diferença que estamos conceituando; é ela que estamos perseguindo; é dela que estamos falando. Portanto, mesmo sendo abordada sob vários ângulos e com diferentes perspectivas, é a diferença que nos move quando, no campo do currículo, nos preocupamos com os modos como se dão as práticas de identificação e separação; as estratégias de resistências e lutas; a produção de significados; as tecnologias de governo; as formas de representação; a visibilidade ou negação das culturas e dos saberes; os processos de inclusão/exclusão e de ensino e de aprendizagem nos currículos, nas pedagogias, nos diferentes artefatos culturais, nas escolas e em outros espaços sociais.

Assim, entendendo a centralidade da diferença na contemporaneidade e suas múltiplas possibilidades de encaminhamento e problematização, este artigo focaliza processos de diferenciação ocorridos nos currículos escolares que tenho investigado para mostrar, por um lado, como as formas de um currículo são capazes de produzir rotinas, aprisionar as forças, dividir e desanimar. Por outro lado, este trabalho também pretende mostrar que a diferença, entendida como motor da vida Deleuze (1988), pode sempre ser reativada, já que na vida é sempre possível um encontro ou uma conexão capaz de reativar forcas, ativar devires e produzir alegrias.

Para pensar possibilidades de liberação das forças de um currículo, que se encontra tão preso às formas, trago, como exemplo, movimentos da personagem Maria Margarida ou Fada Docine do tocante livro "A 
contadora de filmes" do chileno Hernán Rivera Letelier. Isso porque o devir-artista da personagem é exemplar de como de toda "forma" que dói, que entristece, que paralisa o movimento e a vida se pode retirar uma "força" que faz delirar; produzindo, assim, rupturas na forma e fazendo conexões com aquilo que produz alegrias. Afinal, resgatar as forças é reaver aquilo que é próprio da vida e que vem antes e primeiro, ainda que o antes e o primeiro, aqui, não obedeça a nenhuma ordem cronológica.

Nas partes que se seguem, portanto, apresento, primeiro, como os currículos que tenho investigado se apegam às formas e vão bloqueando as forças. Em seguida, apresento uma breve síntese do livro A contadora de filmes, de Letelier, para abordar o devir-artista de Maria Margarida como inspirador para fazer cortes nas formas de um currículo, liberar as forças e mobilizar a diferença, que é fluxo para uma vida. Por fim, discuto possibilidades de algumas dessas forças para mostrar a importância de bons encontros em um currículo: aqueles que aumentam a potência de existir e agir de uma professora e de seus/suas alunos/as.

\section{II - FORMAS EM UM CURRÍCULO}

Muitas crianças chegam ali na escola com muitas expectativas: "vim para aprender", "vim para fazer amigos", "vou aprender a ler", "vou aprender a ler e a escrever", "vou conhecer gente nova", "quero aprender muito", "quero conhecer coisas diferentes", "quero estudar"... Algumas não têm tantas expectativas, mas sabem que é importante ir à escola: "não sei o que vou aprender [...], é importante estudar"; "minha mãe disse que eu tenho que estudar"; "vou para aprender coisas que a professora ensinar". As professoras, por sua vez, muitas delas, estão esperançosas (a cada nova turma ou a cada novo projeto), estão empenhadas em ensinar e querem que as crianças aprendam: "o objetivo é fazer o aluno aprender"; "todas aqui estamos unidas por um único desejo: possibilitar a aprendizagem para todos"; "não vale usar essa conversa de família desestruturada"; "mesmo as crianças que têm famílias desestruturadas têm que aprender"; "problemas todo mundo tem, então temos que procurar meios de enfrentá-los"; "vamos fazer os alunos que possuem baixo desempenho aprender, custe o que custar".

O problema é que as formas de um currículo acabam com muitas dessas expectativas, forças e decisões. Isso ocorre não porque no currículo não acontece nada. Mas sim porque as formas dos currículos imprimem rotinas, demandam repetições do mesmo, exigem organizações e ordenamentos, priorizam o ensino. As formas dos currículos prescrevem, enquadram, formatam, generalizam, repetem o mesmo, limitam. Tudo isso impede o escape e a expansão; dificulta as conexões; aprisiona o desejo e bloqueia as forças.

Sim, em um currículo, diferentemente do que se tem divulgado em alguns discursos, se ensina muito. São muitos conteúdos e saberes ensinados. Muitas habilidades e competências são perseguidas. Inúmeras atividades e muitos exercícios são praticados. Os roteiros rotineiros são seguidos ainda que esgotando todas as forças de uma professora e de seus/suas alunos/as. Ao acompanhar, por exemplo, atividades de leitura e escrita ensinadas em algumas aulas de português para crianças/jovens que estão se alfabetizando, fica evidente como apesar do cansaço e da fadiga de uma professora que tanto ensina e do aborrecimento de alunos/as com o currículo-forma, com a repetição e a grande quantidade de exercícios, inúmeras atividades de escrita e de leitura ganham forma e ocupam todo o currículo, não deixando espaço para encontros surpreendentes.

Trago aqui, para exemplificar, uma lista de atividades praticadas apenas nos seis primeiros meses de um ano letivo com crianças/jovens em processo de alfabetização: escrita e leitura de letras, sílabas, palavras, frases, pequenos textos (muitos textos; os mais variados). Ditados (muitos ditados). Quebra-cabeça com frases, com palavras, com letras. Jogos de encontrar palavras em textos, de encontrar letras em palavras, em placas de carros, em nomes de ruas, em títulos de livros. Jogos de dizer qual a letra das placas de carro vem antes e qual vem depois no alfabeto. Atividades de encontrar palavras em jornais, em revistas, em histórias, em músicas, em sites da internet... Jogo de caça-palavras e de reforma ortográfica em sites da internet (www.imagem.eti.br).

Escrita do que pensam que é gíria e de gírias faladas pelos/as alunos/as. Produção de textos com base em leituras de reportagens (muitas reportagens). Escrita de histórias em quadrinhos. Escrita de relatórios das aulas de informática, de passeios realizados pela escola, de atividades feitas nos feriados e nas férias. Escrita de receitas (várias receitas). Escrita de frases com muitas palavras indicadas pela professora, tais como: cinquenta, enxágue, pinguim, heroico, ideia, tranquilo, pera, para, Chacrinha, amarela, mascote, gincana etc. Escrita de texto sobre a expectativa de uma excursão programada a um clube; do que imaginam que vai acontecer em uma partida de futebol; do que imaginam que vai acontecer em um capítulo da novela. Escrita de um texto sobre a biografia de Chacrinha. Escrita de histórias em um site da internet.

Leitura de palavras, de músicas, de livros de literatura, de jornais, de livros, de trechos de livros pela professora e pelos alunos. Leituras e reescritas de histórias em quadrinhos da "Turma da Mônica". Leitura e inúmeras atividades de escrita do livro "A bolsa amarela" de Lygia Bojunga. Sugestões de palavras (verbo, sujeito, adjetivo) 
para que um site crie uma história (http://guida.querido. net/jogos/portug/adject-2htm). Leitura e escrita de frases para serem usadas em jogos com mímicas. Leitura e escrita de resumos de vídeos. Leitura e escrita de nomes de produtos encontrados em uma lojinha da escola. Leitura e escrita sobre a utilidade de determinados objetos tais como: apontador, régua, sabonete, brinco, colar, lápis, caderno...

Esta é uma lista resumida e incompleta de atividades realizadas em um currículo na busca por ensinar a ler e a escrever. Apesar de sua incompletude, ela é suficiente para mostrar porque no cotidiano de um currículo em curso é difícil ver encontros potentes acontecendo. Um encontro potente é aquele que leva a "encontrar a diferença de cada um", que o faz "seguir um caminho que ainda não foi percorrido" (PARAÍSO, 2011, p. 3) e lhe traz alegrias. Assim, não é por falta de ensino, nem de exercícios, nem de atividades, nem de rotinas, nem de disciplina, nem de organização que não temos encontros potentes que fazem aprender em um currículo. Ao contrário, penso que vale a pena pensar que um dos problemas da dificuldade de aprender pode estar exatamente aí: na repetição extenuante das atividades. Pois o que tenho visto é que tudo isso - a repetição de exercícios, a busca por um mesmo desempenho, o não se antenar com a diferença de cada um - vai pouco a pouco produzindo a fadiga nos/as alunos/as e a angústia na professora, ao ponto de todos/as concluírem que algo vai mal, muito mal na escola e no currículo.

É claro que ao nomear o que vai mal muitas hipóteses são apresentadas por alunos/as e professores/as. Às vezes, o problema é atribuído aos/às alunos/as e à sua família: "falta ajuda das famílias"; "as mães também não ajudam, né?"; "são meninas muito agitadas"; "eles não querem saber de nada"; "são alunos difíceis demais"; "eles não ligam para a escola". Outras vezes, os/as alunos/as atribuem a si mesmos/as o problema: "Estou cansado"; "tenho preguiça, fessora"; "estou com sono", "estou desanimado", "não consigo". Algumas hipóteses expressam avaliações que remetem claramente ao problema do currículo-forma: "eu cansei disso, quero ir embora"; "esse texto é esquisito"; "a professora cismou com o Chacrinha [...] não sei para quê. Ele já até morreu"; "eu não gosto dessas aulas, mas prefiro isso do que fazer serviço de casa"; "eu não vim mais, fessora, porque cansei disso aqui"; "ai, todo dia é só isso" (reclama mostrando uma folha com exercícios). Diálogo: “- você terminou suas atividades? - Atividades? Ah fessora... não aguento mais isso!"

Quando as expectativas são frustradas e os sonhos acabam; as rotinas pesam e desanimam; a fadiga e o desinteresse se explicitam e as divisões se multiplicam: "bons e maus" alunos, "interessados e desinteressados", alunos "com bom e com baixo desempenho", "organizados e desorganizados", "indisciplinados e obedientes", "desatentos e atenciosos", "inteligentes e com dificuldades", "normal e com defasagem", "meninas agitadas" e "meninos desorganizados" etc. - as divisões e diferenciações iniciais se transformam explicitamente em hierarquizações, explicações e justificativas para resultados nas avaliações, para comportamentos e para outras práticas curriculares que, por sua vez, trazem outras formas ao currículo. Um currículo quando se formata demais, espalha tristeza, desânimo ou indiferença.

Quando o desânimo e a tristeza invadem um currículo, o aprender se distancia. É necessário, então, fazer um corte nisso tudo. É necessário algo movido pela diferença, que tudo metamorfoseia, para levar vida a um currículo. É necessário que algo aconteça, toque e que convenha para a vida daqueles/as que ali estão. Aprendi da filosofia de Spinoza (2007) que o impulso que empurra ao crescimento é resultado de uma dinâmica dos "encontros de um corpo" (p. 119). Alguns encontros se mostram como alimento para o crescimento e outros encontros diminuem a capacidade de ação (SPINOZA, 2007). Então, nesse modelo de crescimento "alimentar" de Spinoza, as diversas partes de um corpo precisam alimentar-se para viver e crescer. Como as partes são diversas, também os alimentos terão que ser diversos. É fundamental para o funcionamento de um corpo em geral que a alimentação esteja equilibrada. Nesse sentido, a nossa grande busca, nos termos spinozistas, deve ser conhecer os alimentos que convêm a um corpo; aquilo que nos convém porque "aumenta" ou "estimula" nossa "potência de agir" (SPINOZA, 2007, p. 163). O afeto é, portanto, de importância vital para um corpo. Afinal, somos sempre afetados por outros corpos com os quais nos encontramos. E o afeto, como explicita Spinoza (2007), são "as afecções do corpo, pelas quais sua potência de agir é aumentada ou diminuída, estimulada ou refreada" (SPINOZA, 2007, p. 163).

Com base nesse pensamento, então, posso dizer que, para transformar os encontros tristes de um currículo, é importante conhecer, espreitar, perguntar, problematizar, encontrar uma "linha de fuga" (DELEUZE, 1992); não se entregar; mas sempre revitalizar e "experimentar" (DELEUZE, 1997a). Perguntar talvez: Como posso transformar, transfigurar, desformatar esse/nesse currículo que está produzindo tristezas? O que mobiliza minhas forças? $\mathrm{O}$ que me faz feliz em meu trabalho de educadora? O que me faz feliz em minha vida de estudante? Que novidade pode fazer esse currículo revitalizar aqui e agora? O que pode servir como um convite à modificação da existência em um currículo, como o é a filosofia para Spinoza?

Como não sabemos antecipadamente com que corpo podemos fazer um bom encontro, é necessário 
experimentar. ${ }^{3}$ Buscar inspiração em outros lugares, coisas e objetos para mobilizar a diferença e agenciar devires que produzam alegrias em um currículo e em uma vida. Maria Margarida, personagem do livro A contadora de filmes, descobriu o que a fazia feliz e era capaz de mudar o seu viver: contar filmes. Foi experimentando que ela encontrou um caminho por fazer. Foi experimentando que ela transformou suas próprias dores e tristezas. Do seu encontro com os filmes e o cinema, Maria Margarida retirou a capacidade de alegrar-se e de entrar em devires. Com o devir-artista Maria Margarida entra no tempo do intempestivo; no espaço do caminho por-fazer; na onda dos fluxos de novidades! Tempo, espaço e onda que podem fazer a diferença em um currículo.

Por isso é que interrogo: quem sabe o devir-artista de A contadora de filmes possa também ser inspirador para nós, curriculistas, professoras, estudantes? Quem sabe ele possa inspirar-nos a movimentar para eliminar todos os desânimos, as tristezas e cobranças em um currículo? Quem sabe ele possa nos inspirar a revitalizar, desaprender o dado e o feito e seguir um caminho por-fazer em um currículo? Quem sabe o exemplo desse devir não possa inspirar a sonhar, delirar e contagiar na educação? O tipo de encontro que cada uma de nós pode fazer com um texto, um livro, uma professora, uma experiência ou um corpo qualquer é, realmente, sempre uma incógnita. Contudo, é certo que o devir-artista de Maria Margarida é exemplar de como, mesmo nas circunstâncias mais difíceis, é sempre possível mobilizar as forças, trabalhar com o acaso e entrar em devires.

\section{III - SOBRE A CAPACIDADE DE ENTRAR EM DEVIRES E TRANSFORMAR AS TRISTEZAS}

\begin{abstract}
Ao apagar as luzes todos se endireitavam e ficavam duros na frente da tela. Eu não. Eu virava a cabeça para ver aparecer o raio de luz que saía pelas janelinhas do quartinho de projeção e percorria o espaço sobre nós até se chocar com a tela e explodir em imagens e sons [...]. Eu achava um prodígio que aquele jorro de luz pudesse transportar coisas tão impressionantes como trens perseguidos por índios a cavalo, barcos de piratas em mares de tormenta e dragões verdes exalando fogo por suas sete cabeças (LETELIER, 2012, p. 3).
\end{abstract}

Assim é narrado no livro A contadora de filmes, de Hernán Letelier o encantamento que a garota Maria Margarida sentia quando ia com a sua família ao pequeno cinema no povoado onde morava, no deserto chileno do Atacama, localizado ao lado das indústrias de sal, no final dos anos 50. A sessão de cinema dos domingos é tanto o lugar de ficar "por dentro" das novidades dos famosos atores e das famosas atrizes da época, como o espaço de encontro das pessoas do povoado. É também o local de conversas, de troca de informações, de paqueras e namoros. Além disso, era um dos poucos espaços de contato com o restante do mundo. Para a família de Maria Margarida era o acontecimento mais esperado, almejado, intensamente vivenciado e belamente narrado pela garota/moça/mulher Maria Margarida ou Fada Docine, personagem principal, narradora da história, a filha mais nova e a única mulher dos cinco filhos de uma família de mineiros.

O pai de Maria Margarida era apaixonado pelos filmes e pelo cinema e, mesmo com pouquíssimo dinheiro, já que não passava de um explorado empregado de uma mina de sal, não perdia uma sessão no precário e único cinema do povoado. Contando cada moeda que possuía, ele ia, junto com toda a família, todos os domingos ao cinema. Era o grande momento da semana para todos eles. Para isso, a garotinha Maria Margarida se arrumava meticulosamente sob os cuidados da mãe. Contudo, um acidente de trabalho sofrido pelo pai da menina deixa-o paralítico e traz vários efeitos dolorosos para a família. Um deles é que a mulher/mãe vai embora deixando o pai com grande rancor/ mágoa/ tristeza e um vazio arrasador na vida de Maria Margarida. Outro efeito devastador é que o acidente corta a renda familiar pela metade e, a partir daquele momento, somente um dos cinco filhos poderia ir ao cinema aos domingos com a tarefa de contar o filme para o resto da família. Para não perder o prazer que sentia com os filmes, o pai faz um concurso entre os cinco filhos para escolher quem melhor conta a história que assistiu na tela. Maria Margarida é a eleita nesse concurso. A partir daí, todos os domingos, ela vai ao cinema sozinha e se transforma na contadora de filmes de sua casa.

É nesse momento de corte, de ruptura e de dor que Maria Margarida descobre o enorme talento que possui para narrar, contar e interpretar. Talento esse reconhecido e admirado não somente pelo seu pai e irmãos como por todos do seu povoado. Ao descobrir seu próprio talento, Maria Margarida mergulha em leituras sobre filmes, sobre os atores e as atrizes, sobre suas vidas, sobre o cinema. Vai, aos poucos e instintivamente, se aperfeiçoando como contadora de filmes. Busca materiais para usar em suas narrações. Roupas e adereços são acrescentados. Além disso, Maria Margarida passa a incorporar detalhes que passavam despercebidos para os espectadores, para dar mais ênfase às suas narrações: "a forma acanalhada da loura amante do mafioso pintar os lábios, um tique quase despercebido do pistoleiro nos instantes que antecediam o sacar do revólver, a forma em que os soldados acendiam o cigarro nas trincheiras para que o inimigo não visse o fulgor do fósforo" (LETELIER, 2012, p. 35-36).

Mergulhada nesse outro mundo que ela criou e que era sua fonte de felicidade, Maria Margarida, em seu devir- 
artista, se transforma em Fada Docine e na contadora de filmes da região. Suas narrativas eram revestidas de tal encantamento que os vizinhos passaram a frequentar sua casa, preferindo, muitas vezes, vê-la contar do que assistir ao filme na tela grande. Suas narrativas emocionavam, encantavam e transportavam as pessoas para outros mundos. Fascinada com essas narrativas, uma dessas espectadoras comenta com o pai da menina: "Sua filha é uma fada contando filmes, vizinho, e sua varinha mágica é a palavra. Com ela, nos transporta" (LETELIER, 2012, p. 48). Aliás, foi escutando essa frase que Maria Margarida, que já estava procurando um nome artístico, porque "se sentia uma verdadeira artista", encontrou o nome que ela considerou que lhe caía perfeito: Fada Docine! A partir daí, ela já não era uma, mas duas ou mais; e uma outra existência se tornou possível e praticada

Posso estabelecer diferentes conexões com esse livro porque ele aborda temáticas que me tocam profundamente: a comovente infância, puberdade, adolescência e vida adulta de uma garota/moça/mulher vivendo em um povoado sem recursos; a violência de gênero e classe sofrida pela garota e toda a destruição que ela provoca; todas as consequências do crescimento de uma garota em uma família pobre cercada por homens; a emocionante relação mãe e filha e todo o sofrimento provocado por um corte na relação; o modo como uma família pobre vai se decompondo; os efeitos de uma ditadura e suas turbulências sobre todos e tudo. Trata-se de um livro poético-político que produz emoções particulares e que, na sua simplicidade, choca, encanta e intriga. Contudo, quero aqui seguir a linha das formas e das forças, para compreender a possibilidade do pulsar da diferença, para sentir a capacidade de transformação da tristeza e para aprender sobre a força dos devires, que pode nos inspirar na educação.

Deleuze e Guattari (1997a) explicam que "devir é rizoma, contágio" (p. 19). O devir apenas pode ser pensado, em toda sua consistência, como sendo, como acontecendo, como sucedendo. Quando pensamos em devir, devemos pensar em possibilidade. O devir é meio, é estar-entre, é passar-entre. Deleuze e Guattari dizem que "o devir está sempre no meio, só se pode pegá-lo no meio. Um devir não é um nem dois, nem relação de dois, mas entre dois, fronteira ou linha de fuga, de queda, perpendicular aos dois" (DELEUZE; GUATTARI, 1997a, p. 91). Sendo assim, ao pensar o devir, pensa-se em movimento. Todo aquele movimento pelo qual a linha libera-se do ponto, atravessa o ponto, corta os acontecimentos e quebra as formas, caracteriza o devir. No devir não há evolução, mas simbiose; não há desenvolvimento, mas aliança, não há ilustração, mas composição; não há imitação, mas contágio. No contágio há fusão e, nela, a possibilidade de que algo novo surja.
A garota Maria Margarida estava em um mundo em que as forças estavam capturadas; as alegrias arrasadas e a dor estava aniquilando a vida. Contudo, do seu encontro com os filmes, ela vê uma chance para fazer a vida pulsar e para entrar no pulsar da vida. Um "bom encontro", como na ética de Spinoza, para quem o "bom" e o "mau" são noções relativas (SPINOZA, 2007). Bom é aquilo que me cai bem e mau aquilo que me cai mal. E isso não tem que ser assim para outras pessoas. Os filmes e o cinema são bons para Maria Margarida porque trazem alegrias e a possibilidade de uma outra existência para si mesma e para outros. Com os filmes e o cinema ela volta a ver beleza em cada comportamento e em cada possibilidade de experimentar. É pelos filmes e pelo cinema que Maria Margarida volta a se preparar meticulosa e alegremente para os encontros e para a vida. Sobre esse momento de suas apresentações Maria Margarida relata:

Era lindo, depois de ver o filme, encontrar meus pais e meus irmãos me esperando ansiosos em casa, sentados enfileirados que nem no cinema, penteadinhos e de roupa limpa, recém-mudada. Meu pai, com uma manta boliviana cobrindo as pernas, ocupava a única poltrona que a gente tinha, e assim era a plateia lá de casa. [...] A galeria era aquela bancada comprida, de madeira bruta, onde meus irmãos se acomodavam em ordem, do menor ao maior. Depois, quando alguns de seus amigos começaram a aparecer na janela, a janela virou o balcão. Eu chegava do cinema, tomava rapidinho uma xícara de chá (que deixavam pronto me esperando) e começava a minha função. De pé na frente deles, de costas para a parede pintada de cal, branca feito a tela do cinema, começava a contar o filme 'de a a z', como dizia meu pai, tratando de não esquecer nenhum detalhe, nem da história, nem dos diálogos, nem dos personagens (LETELIER, 2012, p. 48).

Sim, essa experiência era pura felicidade; um mundo de sensações novas; um novo existir. O programa ético de Spinoza consiste em sermos mais conscientes das causas que determinam nossos desejos e nossas alegrias porque assim nosso comportamento será mais ativo, mais potente e mais livre (SPINOZA, 2007). Isso significa uma coisa como: buscar a ser conscientemente aquilo que se é inconscientemente. Maria Margarida sabia as causas de suas alegrias; sabia que era boa no que fazia, mas se aperfeiçoava ainda mais, a cada dia, porque isso a fazia feliz. Aliás, boa não; Maria Margarida sabia que era "a melhor"! Em suas palavras: "assim mesmo, como se ouve: a melhor contadora de filmes da família. Depois passei a ser a melhor da viela e em pouco tempo a melhor do povoado" (LETELIER, 2012, p. 32). Maria Margarida era "a melhor" porque sempre teve com os filmes um bom encontro: aquele que aumenta a potência de agir e produz alegrias (SPINOZA, 2007, p. 181). Maria 
Margarida deixava-se contagiar pelo mundo dos filmes e dos/as artistas e entrava em um devir-artista para artistar seu mundo. Fazia simbiose, composição, aliança com as diferentes histórias dos filmes que via e se transforma na Fada Docine, abrindo-se a um mundo novo. Afinal, no devir-artista tudo é possível, tudo é permitido porque seu trabalho é inventar outros possíveis. A criação é a própria matéria para inventar o mundo. E a Fada Docine era "uma artista completa" (LETELIER, 2012, p. 32) - como dizia seu pai - que usava tudo o que podia em suas artistagens para transportar-se e transportar outros/as a um outro mundo que ela mesma inventava.

Sobre sua busca incansável para aperfeiçoar-se ela diz: "passado algum tempo, já não me conformei só com a mímica e as mudanças de voz, e incorporei elementos externos, como no teatro. [...] Depois comecei a fabricar o meu próprio material cenográfico" (LETELIER, 2012, p 36). Em seu devir-artista ela também fazia chorar de emoção, rir, se encantar, "flutuar". Ela criava, inventava, imaginava os acontecimentos para narrá-los, completava histórias, floreava as narrações, esmerava, fabulava, vivia o filme. "Acho que no fundo eu tinha alma de fuxiqueira, pois além de tudo, me bastava bater os olhos nas duas ou três fotos pregadas no cartaz [...] para poder inventar uma trama, imaginar uma história inteira e passar o meu próprio filme" (LETELIER, 2012, p. 38).

Sim, Maria Margarida, em seu devir-artista, é exemplar de como é possível transformar as tristezas; buscar o que se quer ser; fazer um corte nas formas que impedem as forças. "Eu queria ser outra coisa na vida. Não sabia o que, mas outra coisa" (LETELIER, 2012, p. 24). É por isso que Maria Margarida busca conhecer esta outra coisa que ela queria ser e que lhe trará alegria. Ao cortar as formas do mundo que habitava, abrem-se possibilidades de ramificações que a arrastam para um mundo que ela ajuda a inventar. São as ramificações que permitem seguir um caminho que põe de novo a vida em movimento e o movimento na vida. Como ela mesma fala sobre uma lição que aprendeu de sua mãe: "por que se conformar com ser vaga-lume, digo eu, podendo ser estrela?" (LETELIER, 2012, p. 24). É esse movimento de liberação e de abertura feito por Maria Margarida em seu devir-artista que desejo para um currículo. É ele que busco aprender a fazer com os currículos.

É bem verdade que nos currículos que investigamos, dizemos e fazemos é possível ver lampejos de devires, de forças, de diferenças, porque apesar de todas as formas, de todos os poderes e de todas as identificações, a possibilidade existe em tudo e em todos os momentos. As forças estão ali, aqui e acolá à espera de algo que as façam explodir. A diferença, que vem antes, está à espera de uma brecha para iniciar seus jogos. ${ }^{4}$ É possível ver, por exemplo, uma professora cega, artis- tando com seus/suas alunos/as, entrando no jogo da diferença e fazendo de conta que, por não enxergar, não sabe qual palavra, frase ou texto está trabalhando. Com esse jogo, a professora faz matilha e conexões com seus/suas alunos/as que querem saber ler para ajudar a professora que não enxerga. Inicia-se aí a uma boa composição que, como o Zaratustra de Nietzsche, possibilita o devir-transformação e coloca em ação os jogos, os risos e as alegrias. ${ }^{5}$

Contudo, esses momentos de artistagem, de transmutação, de composições são poucos em um currículo exatamente pelo apego às formas, aos programas, aos desempenhos. Esses poderes muitas vezes impedem as professoras de fazer o que querem e têm capacidade para fazer. Eles são sentidos pelas professoras (e também pelos/as alunos), fazendo-as viver e praticar a educação de modo estéril, sem alegria, tristemente e muitas vezes até doentemente. É por isso que é necessário que algo se passe para que seja possível no território curricular ver, perceber e sentir diferente do que se tem vivido e sentido na escola.

Do encontro com Maria Margarida (e seu mundo de artistagens), com Gilles Deleuze (e seu mundo de devires) e com Spinoza (e seu mundo de encontros potentes), retiro algumas aprendizagens para movimentar o currículo-forma: é necessário sermos mais atentas e conhecedoras das causas que determinam nossos desejos e alegrias! Nem ridicularizar, nem lamentar; mas buscar ser mais consciente dos efeitos dos encontros! Transformar generosamente as tristezas! Deixar a diferença entrar, dançar, movimentar, "fazer seus jogos"! Multiplicar os bons encontros em nome da alegria! Pois essas aprendizagens - que Maria Margarida parecia saber tão bem desde garotinha e que de vez em quando podemos ver e sentir em um currículo - parecem bons caminhos para fazermos um currículo coincidir com a vida e inventarmos outros possíveis na educação.

\section{IV - PODE UM CURRÍCULO SER VETOR DE FORÇA E MOBILIZADOR DA DIFERENÇA?}

Considero que um currículo, apesar de ser constituído de muitas formas, pode perfeitamente ser feito da mesma matéria dos sonhos, dos filmes e da vida. Para isso é necessário fazer muitos cortes nas formas que aniquilaram as forças; deformar as regras; arriscar; seguir o movimento da vida; atentar às sensações nossas e de nossos/as alunos/as. Um currículo, livre das formas que aprisionam, trabalha com a diferença para encontrar os desejos dos diferentes, para enfatizar as suas dinâmicas, reforçá-las e problematizá-las. Trabalha com a diferença não para justificar e fazer diferenciações, mas para atentar às forcas que produzem bons encontros e para 
dar alimento para a diferença seguir seu fluxo. Isto porque, como sugere Corazza (2005), "as diferenças puras dos diferentes não são para, simplesmente, serem respeitadas, ou para funcionarem como ponto de partida de nada. [...] É por suas alteridades que estamos sendo interpelados e desafiados" (p. 20). É a diferença pura dos diferentes que pode deformar um currículo e mobilizar as forças. Diferença que, na perspectiva de Deleuze (1988), é mobilizadora de conexões com saberes, com alegrias, com a vida; é liberadora das forças vitais; é potencializadora de expansões do e com o mundo.

Para que um currículo seja feito da mesma matéria da vida é preciso saber que quando meu corpo se encontra com outro me faz bem ou mal (SPINOZA, 2007, p. 119). Se as relações características do outro corpo se harmonizam com o meu, porque são velocidades ou ritmos parecidos ou coincidentes, o resultado é uma composição. Quando, ao contrário, o encontro se produz com um corpo que não me convém, atua como um veneno, me debilita, enfraquece, porque tenho que investir energia e tempo para digeri-lo, enfrentá-lo ou expulsá-lo (SPINOZA, 2007, p. 185). A força que invisto para enfrentar um corpo que não me fortalece é força perdida. Assim é que minha potência aumenta ou diminui.

Usando esse raciocínio spinozista para as matérias de um currículo, podemos todos/as (professores/as e estudantes) dizer: por um lado, essa matéria, essa atividade, esse encontro, esse/a colega, essa/e professor/a, esse saber aumenta minha potência. Por outro lado, essa matéria, essa atividade, essa/e professor/a, esse saber me entristece e diminui minha potência. Ao conhecer o que nos alegra e o que nos entristece em um currículo podemos ter elementos para reforçar as alegrias e então seguir a linha do aprender. Sabemos que muitas forças estão sendo perdidas em um currículo. Sabemos que há muitos encontros tristes em um currículo, assim como o há na vida. Por isso é muito importante sabermos fazer essas identificações. Afinal, da ética de Spinoza e também dos textos de Deleuze sobre Spinoza podemos apreender que, apesar de todas as partes, corpos, matérias que, em seus encontros, produzem doenças, tristezas, desgastes, preguiças, enfraquecimentos, não existe nada mais no mundo do que o impulso à vida. Então, em qualquer momento esse impulso à vida pode nos tocar e transformar as tristezas. Essa é uma importante tarefa do currículo-força que coincide com a vida, mobiliza a diferença e deforma os enquadramentos e as diferenciações que entristecem.

Sim, desfazer, desconstruir e desmontar as formas dos currículos, os raciocínios que dividem e confinam e as verdades que aprisionam é um importante trabalho de um currículo vetor de forças e mobilizador da diferença. Nessa tarefa, é necessário "desfazer incansavelmente os eus e seus pressupostos; [...] liberar as singularidades pré-pessoais que eles encerram e recalcam" (DELEUZE; GUATARRI, 1997b, p. 134). É necessário encontrar a diferença de cada um e atentar aos bons encontros de um currículo: aqueles que aumentam a nossa potência de existir e de agir e, consequentemente, nos trazem alegrias.

Com base em Spinoza (2007), é possível dizer, então, que existem indicadores que nos guiam nessa tarefa de sabermos reconhecer o que é bom e o que é mau para nossos corpos. Quando encontro outro corpo que me convém, sei que é bom para mim porque me sinto alegre. Quando encontro um corpo que não me convém me sinto triste. A alegria e a tristeza são, portanto, os indicadores primeiros do trânsito para o aumento ou a diminuição da potência. Eles podem também ser bons indicadores em nossas docências daquilo que devemos transformar e daquilo que devemos multiplicar em um currículo. Dos bons e dos maus encontros derivam o ódio e o amor. Amamos o que nos produz alegrias e odiamos o que nos produz tristeza. É nisso que podemos nos apoiar para desenvolver nosso trabalho, nossa docência, nossas aulas, ainda que isso não seja suficiente, já que as alegrias e as tristezas são passageiras e volúveis (SPINOZA, 2007). Mas isso é, certamente, um bom começo; um bom critério para selecionarmos atividades e saberes nas escolas; um bom indicador para avaliarmos nossas práticas e o efeito do que ensinamos sobre nossos/as alunos/as. A partir daí podemos tentar organizar os encontros, favorecendo aqueles que nos produzem alegrias e afastando aqueles que nos entristecem.

Spinoza lembra que só a alegria nos ajuda a sair do mundo dos signos (SPINOZA, 2007). É ela que possibilita a passagem do "conhecimento perceptivo" ao "conhecimento racional" (SPINOZA, 2007, p. 349). Mas a tarefa da razão (ou a função do conhecimento racional) não é, em Spinoza, pensar, nem dialogar a partir de ideias gerais, mas sim criar noções comuns; encontrar e formular verdades sobre as relações; e compreender as sensações ou paixões que as relações nos produzem (SPINOZA, 2007, p. 347). Eis aí tarefas importantes para um currículo construído da mesma matéria dos sonhos, dos filmes e da vida. Um currículo assim construído muda sua lógica e seus critérios; abre-se para todas as possibilidades e aceita experimentar novas conexões. Frente a um currículoforma que pratica atividades repetidas, indiferentes aos gostos, aos efeitos dos encontros e às sensações que produz, imaginar que tudo está por ser feito, que tudo pode ser feito de outro modo, que inúmeras possibilidades existem em um currículo e na vida.

Então, o que um currículo-vetor-de-forças pode fazer? Abrir-se para as possibilidades de uma vida! Abrirse à experiência com "um outro", com "outros". Deixar os corpos permanentemente abertos porque é assim que as 
partes podem se conectar com outras diferentes partes e com outras coisas insuspeitadas e, então, um corpo pode ser levado "imediatamente a uma diferença" (GIL, 2002, p. 216-217). A diferença? Sim, "é essa diferença que vai provocar a osmose profunda" (GIL, 2002, p. 217). Afinal, foi pela valorização da diferença, pela vivência e reconhecimento de suas experiências que "os diferentes desequilibraram as relações conhecidas, dissiparam a segurança identitária, tornaram estranho tudo o que antes era tão familiar. Para que, junto com eles, assumíssemos a responsabilidade ética de educá-los em sua própria diferença” (CORAZZA, 2005, p. 20).

Desaprender! Desfazer! Desarrumar! Aumentar sem limite o bom humor, o abrir-se às sensações, o alegrar-se com o conhecimento de nós mesmas/os e de nossos/as alunos/as. Praticar a generosidade colocando o que sabemos e conhecemos à disposição de nossos/as alunos/as para transformar os encontros tristes. Buscar as causas das alegrias nossas e de nossos/as alunos/as! Conhecer as combinações potentes, as afinidades e as afirmações! Conhecer aquilo que, quando combinado, amplia nosso próprio impulso vital! Estas não podem mesmo ser boas tarefas para o currículo-força que queira fazer cortes nas formas e abrir um novo caminho a percorrer na educação?

Sabemos que não é fácil vivenciarmos um currículo tão abertos/as aos encontros. Temos dificuldade de praticar a docência sem um caminho que nos pareça seguro e sem sabermos antecipadamente no que vai dar os encontros que vamos articular no território curricular. Tudo isso requer soltura, desprendimento, planejamento diário e constante, postura aberta para a vida! Até mesmo Spinoza reconhecia que construir uma vida assim, aberta aos encontros, é uma tarefa árdua. Contudo, como o próprio filósofo argumentava - e esta é a frase com que termina a sua Ética e que eu uso para finalizar este artigo -, "tudo o que é precioso é tão difícil como raro" (SPINOZA, 2007, p. 411).

\section{REFERÊNCIAS}

ARTAUD, Antonin. Oeuvres completes. Paris: Gallimard, 1978.

ARTAUD, Antonin. Para terminar con el juicio de dios y otros poemas. Valencia: MCA, 2001.

ARTAUD, Antonin. El teatro y su doble. Barcelona: Edhasa, 2006.

CORAZZA, Sandra. Uma vida de professora. Ijuí: Unijuí, 2005.

DELEUZE, Gilles. Nietzsche e a filosofia. Rio de Janeiro: Editora Rio, 1976.

DELEUZE, Gilles. Diferença e repetição. Rio de Janeiro: Graal, 1988.
DELEUZE, Gilles. Conversações - 1972-1990. São Paulo: Editora 34, 1992.

DELEUZE, Gilles. Foucault. São Paulo: Brasiliense, 1998.

DELEUZE, Gilles. El intelectual y la política: sobre Foucault y la prision (Entrevista com Giles Deleuze). Archipiélago, Barcelona, n. 53, p. 68-74, 2002.

DELEUZE, Gilles; GUATTARI, Félix. O que é a filosofia. São Paulo: Editora 34, 1992.

DELEUZE, Gilles; GUATTARI, Félix. Mil platôs: capitalismo e esquizofrenia. São Paulo: Editora 34, 1995a. v. 1.

DELEUZE, Gilles; GUATTARI, Félix. Mil platôs: capitalismo e esquizofrenia. São Paulo: Editora 34, 1995b. v. 2.

DELEUZE, Gilles; GUATTARI, Félix. Mil platôs: capitalismo e esquizofrenia. São Paulo: Editora 34, 1996. v. 3.

DELEUZE, Gilles; GUATTARI, Félix. Mil platôs: capitalismo e esquizofrenia. São Paulo: Editora 34, 1997a. v. 4.

DELEUZE, Gilles; GUATTARI, Félix. Mil platôs: capitalismo e esquizofrenia. São Paulo: Ed. 34, 1997b. v. 5.

GAUTHIER, Clermont. Esquizoanálise do currículo. Educação e Realidade, Porto Alegre, v. 27, n. 2, p. 143-156, jun./jul. 2002.

GIL, José. Ele foi capaz de introduzir no movimento dos conceitos o movimento da vida: Entrevista. Educação e Realidade, Porto Alegre, v. 27, n. 2, jun./jul. 2002, p. 205-224.

LETELIER, Hernán Rivera. A contadora de filmes. São Paulo: Cosac Naify, 2012.

ORLANDI, Luis. (Org.). A diferença. Campinas: Ed. UNICAMP, 2005.

PARAÍSO, Marlucy Alves. Contribuições dos Estudos Culturais para o currículo. Presença Pedagógica, Belo Horizonte, v. 10, n. 55, p. 53-61, jan./fev. 2004

PARAÍSO, Marlucy Alves. Currículo, desejo e experiência. Educação e Realidade, Porto Alegre, v. 34, n. 2, p. 277-293, maio/ago. 2009.

PARAÍSO, Marlucy Alves. Diferença no currículo. Cadernos de Pesquisa, São Paulo, v. 40, n. 140, p. 587-604, 2010a. http:// dx.doi.org/10.1590/S0100-15742010000200014

PARAÍSO, Marlucy Alves. (Org.). Pesquisa sobre currículos e culturas: temas, embates, problemas e possibilidades. Curitiba: Editora CRV, 2010b.

PARAÍSO, Marlucy Alves. O currículo entre a busca por "bom desempenho" e a garantia das diferenças. In: SANTOS, Lucíola et al. (Org.). Convergências e tensões no campo da formação e do trabalho docente. Belo Horizonte: Autêntica, 2010c. p. 132-152.

PARAÍSO, Marlucy Alves. Currículo e formação profissional em lazer. In: ISAYAMA, Hélder Ferreira (Org.). Lazer em Estudo. Campinas: Papirus, 2010d. p. 27-58.

PARAÍSO, Marlucy Alves. O desempenho como tecnologia de governo de estudantes no currículo. In: PEREIRA, Maria Zuleide Costa; LIMA, Idelsuite de Sousa. (Org.). Currículo e políticas educacionais. Campinas: Alínea, 2012. p. 87-104.

SILVA, Tomaz Tadeu. Manifesto por um pensamento da diferença em educação. In: CORAZZA, Sandra; SILVA, Tomaz Tadeu. Composições. Belo Horizonte: Autêntica, 2003. p. 9-17. 
SPINOZA, Benedictus. Ética. Tradução e notas de Tomaz Tadeu da Silva. Belo Horizonte: Autêntica, 2007.

TORRAS, Meri. Hábeas corpus. Cinco aperturas políticas del cuerpo. In: SCARANI, Stefano; CHINER Julia (Org.). Obertures del cós. Valencia: Universitat de Valencia, 2007. p. 69-72.

\section{Notas}

1 Trecho da música de Lulu Santos "Como uma onda do mar".

2 As noções de forma e de força aqui desenvolvidas são inspiradas, sobretudo, em Artaud (1978, 2001 e 2006) e em Deleuze (1992 e 1998).

3 Toda a obra Mil Platôs, em seus cinco volumes, é um convite à "experimentação". Uma experimentação aberta e afirmativa que me inspira a pensar um currículo como um território a se experimentar. Ver Deleuze e Guattari (1995a, 1995b, 1996, 1997a e 1997b).

${ }^{4}$ Esse convite afirmativo de fazer a diferença iniciar seus jogos é aqui inspirado na frase de Deleuze (1976) "A oposição interrompe seu trabalho, a diferença inicia seus jogos" (p. 89) e retomada no belo "Manifesto por um pensamento da diferença em educação" de Tomaz Tadeu da Silva, que sugere que a diferença é tão leve que ela não trabalha; ela brinca, joga, humoriza, diverte (SILVA, 2003, p. 16).

5 Deleuze afirma: "referidos a Zaratustra, o riso, o jogo, a dança são os poderes afirmativos de transmutação: a dança transmuda o pesado em leve, o riso transmuda o sofrimento em alegria, o jogo do lançamento (os dados) transmuda o baixo em alto" (DELEUZE, 1976, p. 88).

Recebido em setembro 2014

Aprovado em março 2015. 